\title{
Bridging the 'Gap' in Developing Countries: At what Expense?
}

\author{
Chulananda DA Goonasekera \\ University of Peradeniya \\ Sri Lanka
}

\section{Introduction}

Experts from all continents have called for the emerging countries to start chronic kidney disease prevention and screening programs, develop end-stage renal disease registries and start or further strengthen transplantation programs through International as well as regional collaborations to acquire the information, technology, experience and skills necessary whilst acknowledging these goals are ambitious (Remuzzi, Perico, et al. 2010).

Transplantation is the optimal renal replacement therapy for children with end-stage renal disease. Compared with dialysis, successful transplantation in children and adolescents not only ameliorates uremic symptoms but also allows for significant improvement of delayed growth, sexual maturation, and psychosocial functioning. The child with a well-functioning kidney can enjoy a quality of life that cannot be achieved by dialysis therapy (Uchida 2010).

Although renal transplantation is an excellent option for the treatment of uremic children, it is more difficult compared to adults due to different etiologies often congenital, difficult surgical technique(van Heurn and deVries 2009), size match problems of the donor kidney and the post-operative hemodynamic effects due to poorly managed chronic renal failure and its effects upon growth and development. Most importantly, the lack of expertise, financial restraints and low-level national prioritization adds to the problem and prevents the establishment of fully-fledged pediatric renal transplant programs in developing countries (Bamgboye, 2009).

However, despite the negativism (Muthusethupathi \& Shivakumar 1993), many medical personnel in developing countries have attempted to bridge the gap (Usta et al. 2008), often successfully and have developed pediatric kidney transplant programs (Badmus et al. 2005) (Kandus et al 2009). Doctors embarking on such programs would inevitably feel the punch as healthcare in developing countries are less funded than developed nations ( 0.8 to $4 \%$ vs. 10 to $15 \%$, respectively), and must contend against approximately $1 / 3$ of the population living below the poverty line (\$1US/day), poor literacy (58\% males/29\% females), and less access to portable water and basic sanitation. Cultural and societal constraints combine with these economic obstacles. Donor shortage is a universal problem. Post-transplant infections are a major problem in developing countries, with 15\% developing tuberculosis, $30 \%$ cytomegalovirus, and nearly $50 \%$ bacterial infections. The solutions may seem simplistic: alleviate poverty, educate the general population, and expand the transplant programs in 
the public sector hospitals where commerce is less likely to play a major role. This is not forthcoming as in most developing countries it is not the governments' priority. The SIUT model in Pakistan, funded by a community-government partnership is an exception to the rule and sustainable (Rizvi \& Naqvi 1997). Over the last 15 years, it has operated by complete financial transparency, public audit and accountability. The scheme has proven effective and currently 110 transplants/year are performed, with free after care and immunosuppressive drugs. Confidence has been built in the community to attract strong donations of money, equipment and medicines (Rizvi et al. 2003).

According to the databases maintained by North American Pediatric Renal Transplant Cooperate Study (NAPRTCS) and the United States Renal Data System (USRDS) the 1, 2, and 5 year survival rates for primary live donor kidney transplantation (LDKT) were $98 \%, 97 \%$, $95 \%$ respectively. The graft survival rate at 1 year and 7 years for primary LDKT were $92 \%$ and $74 \%$ respectively. According to the United Kingdom Transplant (UKT) report, the graft survival rate for all pediatric recipients during the 1 and 5 year were $79 \%$ and $68 \%$, respectively. Developed centers attribute such excellent results to technical improvements in tissue typing and donor-recipient cross matching, modification of immune-suppression protocols and rigorous donor-recipient selection. (Porrett et al. 2009)

Despite many limitations, Sri Lanka embarked upon a pediatric kidney transplant programme in July 2004 amidst various adversities to offer some hope to children dying of ESRF. Most were transplanted pre-emptively as there was no established dialysis programme for children in Sri Lanka. Renal transplantation is considered pre-emptive if it occurs before the initiation of dialysis and it is not considered detrimental for graft survival compared to dialyzed children (Jung et al. 2010). In the literature, pre-emptive transplantation has been shown not only to reduce the costs of renal replacement therapy but also to avoid the long-term adverse effect of dialysis (Haberal et al 2009) and often involve a live donor that also appear to be slightly more advantageous compared to graft survival rates observed following deceased donor transplantation ( $\mathrm{Ng}$ et al 2009). On the other hand pre-transplant dialysis modality, neither HD nor PD affects the outcome of renal transplantation (Caliskan et al. 2009).

Initiating a pediatric program in a developing country is more difficult (Rizvi et al. 2001). We experienced at the inception, due to lack of chronic renal failure (CRF) or dialysis programme for children, most children presenting late and displaying complications of CRF such as severe anemia, hyper-dynamic circulation, cardiomegaly, metabolic bone disease, growth stunting and poor nutritional state. A plasma urea level of $40-50 \mathrm{mmol} / \mathrm{litre}$ (normal range $2.7-7.0 \mathrm{mmol} / \mathrm{l}$ ) preoperatively was not an uncommon finding. Since preemptive transplantation was the only option, we noted at the initial stages of the programme that, most were not capable cardiovascularly to handle massive fluid and electrolyte shifts that occur during the immediate post transplant period. A polyuric-transplanted adult kidney would bring down the plasma urea to very low levels within 24-48 hours and this contributed to the onset of cerebral edema and convulsions. Inability to monitor plasma cyclosporin levels at short notice also contributed to the high incidence of seizures. Thus, elective mechanical ventilation postoperatively was useful until such time the postoperative polyuric phase was subsiding. Furthermore, the rapid onset pulmonary edema occurred 2-3 days after transplantation in a few cases. This was associated with a rapidly rising CVP, for example, from a stable $12 \mathrm{~cm}$ of $\mathrm{H}_{2} \mathrm{O}$ to $25 \mathrm{~cm} \mathrm{H}_{2} \mathrm{O}$ despite accurate fluid balancing and appeared to be related to a rapid onset-myocardial weakness perhaps precipitated by precipitous electrolyte 
losses (e.g. PO4 $\left.{ }^{3-}\right)($ Sakhaee, 2010) other than what was replaced i.e. Na+ and $\mathrm{K}+$. These patients needed dobutamine as an inotrope to improve cardiac output and resolve pulmonary edema in addition to 1-2 doses of frusemide. Low calcium and low magnesium levels that may ensue due to polyuria could be a contributory factor.

Inadequate chronic renal failure (CRF) supportive care programme led to children presenting for transplantation have many co-morbid factors that made them vulnerable to higher peri-operative and anesthetic risks and difficulties in management. Limited laboratory, operating theatre and supplies of pharmaceutical agents, and the relatively inexperienced work force added to the shortcomings.

Expert inputs from multi disciplinary teams including pediatric nephrologists, transplant surgeons, and pediatric intensivists are imperative to provide optimum care in the perioperative period for the transplant recipient. However, such expertise are hard to come by in the developing world and doctors involved in transplantation should be prepared to exceed their boundaries and provide the care necessary for these children irrespective of the time of the day.

For better outcomes in renal transplantation, it is necessary to optimize medical conditions associated with long-term renal impairment prior to surgery. In the developed world, a kidney transplant centre for children would be supported by many specialists, namely, transplant surgeons, pediatric nephrologists, dieticians, clinical pharmacists, social workers, dialysis teams, home care teams etc to achieve the above set goals. However, this is not feasible for a transplant centre in a developing country. Often the only specialist available would be a general surgeon with transplantation skills, general pediatrician with nephrology interest, and trained nurses. There may not be a social worker, pharmacist, dietician to assist holistic clinical management of the patient. Despite all these drawbacks, the outcomes of kidney transplantation i.e. the graft and patient survival can be similar in developing countries in the short-term, even in children (Wisaanuyotin \& Jiravuttipong 2009) to that of established centers in the developed world, but at what expense? This chapter looks at this issue.

\section{The pre-operative shortcomings}

The pre-operative status of children admitted for renal transplantation in the context of nutritional status, body weight, hemoglobin, and blood urea is far from ideal due to poor management of ESRD resulting from the lack of facilities and inadequacies in dialysis and non-availability of dedicated chronic renal failure management programs. In an ideal centre, they would have their recipients at near normal physical status through aggressive nutritional programs despite being on dialysis.

In our centre, among 29 (20 male) children receiving kidney transplantation aged median 10 years (range 2-16), the mean $( \pm \mathrm{SD})$ pre-transplant hemoglobin and blood urea were $9.36 \pm$ $2.46 \mathrm{~g} / \mathrm{dl}$ and $21.97 \pm 10.17 \mathrm{mmol} / \mathrm{l}$ respectively. Nearly a $2 / 3 \quad(\mathrm{n}=19)$ were on regular antihypertensive treatment. Of them, 1 patient $(3.57 \%)$ had haemodialysis (HD), 7(25\%) peritoneal dialysis (PD) and $3(10.71 \%)$ both prior to transplant. Seventeen $(60.71 \%)$ were pre-emptive transplants. Preoperative blood transfusion to correct anemia was not attempted and it is also considered unimportant to improve outcomes (Aalten et al. 2009). The children in ESRF were cared for in the general pediatric ward, mostly assisted by parents or guardians. Supplementary funding came from external resources. 


\section{The operative difficulties}

In established centers, the operative difficulties in pediatric transplantation are mainly urological (e.g. VUR 12.4\%, ureteral stricture 5\%, anastomotic leak $2 \%$, ureteral necrosis $1 \%$, and incrustative pyelitis $0.5 \%$ ) and vascular (arterial stricture $7.2 \%$, arterial thrombosis $2 \%$, venous thrombosis 1\% ) (Irtan et al. 2010) . Donors aged less than six years were a risk factor of vascular complications leading to graft loss, whereas patients with PUV had more complications that are urological. Overall, patient and graft survival is $93.1 \%$ and $84 \%$ at 5years, respectively. Surgical complications remain a major cause of graft loss $(12 \%)$ and morbidity in children's kidney transplantation (38.9\%).

Among the difficulties encountered during anesthesia, that also has an impact on postoperative care includes poor cardio-respiratory reserve due to cardiomegaly/myopathy (resulting from chronic anemia, uremia and hypertension) and pleural, pericardial effusions, anemia and liver dysfunction. Cardiac dysfunction and excessive bleeding were the commonest complications encountered under anesthesia during operation. It was not uncommon for some children with poor control of hypertension, cardiomyopathy with an EF of $35-40 \%$, and body weight below $3^{\text {rd }}$ centile to be operated.

\section{A unique set of postoperative problems}

In addition to providing good analgesia, the postoperative care of renal transplant recipients include establishment of hemodynamic stability, maintaining adequate perfusion of the newly transplanted kidney and prevention and treatment of complications resulting from fluid imbalance, electrolyte imbalance or myocardial weakness.

The post operative complications encountered in a poorly nourished child with established complications of ESRD such as anemia, osteodystrophy, hypertension, cardiac failure were markedly different to what was described in most published work that involves well prepared, adequately dialyzed and well nourished children who seek kidney transplantation in the developed world.

\subsection{The poly-uric phase}

During the immediate post transplant period the urine output via the transplanted kidney can reach 1-2 liters / hour. Managing this phenomenon in a child of $10 \mathrm{~kg}$ where the total blood volume is only $700 \mathrm{ml}$ can be a daunting task requiring fluid balancing and replacement every 15 minutes. Thus, one patient needs constant attention of several nurses to keep the fluid and electrolytes in balance. Provision of a work force to cater for this need is not an easy task in this part of the world.

During the poly-uric phase, hypokalemia and hypophosphateamia (Sakhaee 2010) are common complications due to unrestrained loss of these electrolytes in urine. This can lead to severe myocardial weakness and arrhythmias. Appropriate cardiac support and anticipation of such problems are needed to be avoided to avert disaster. The potassium loss in the diuretic phase can lead to severe hypokalemia, unless replacement fluids are replenished with at least $5 \mathrm{mmol} /$ liter of $\mathrm{KCl}$.

\subsection{Non functioning transplanted kidney}

The transplanted kidney may not function as a result of well-recognized causes such as, (a) acute rejection (b) acute vascular thromboses and (c) acute tubular necrosis. However, we 
noted several extraneous factors contributing to a non functioning transplanted kidney. These include (a) high CVP (b) high intra abdominal pressure (c) obstructed or leaking ureter and (d) a relatively low systolic pressure that cannot provide adequate perfusion pressure for the transplanted kidney. It was also easy to overload these children, especially in whom the transplanted kidney did not work immediately postoperatively. Thus, careful restraint is also necessary in fluid management to avoid the need for urgent dialysis that is not promptly achievable in this part of the world.

\subsection{Heart failure and pulmonary edema}

This is usually seen $24-48$ hours after transplantation during the latter part of the poly-uric phase. The onset of pulmonary oedema can be very rapid and florid (within a few minutes) and can occur even with meticulous fluid balancing. Thus, it is likely that an acquired myocardial weakness contributing to this complication, most probably due to electrolyte depletion especially phosphate. It should be noted that even in advanced centers, nearly $1 / 3^{\text {rd }}$ of post transplant deaths are attributed to cardio-vascular events (Koshy et al 2009). However, some other centers that record a low mortality rate following pediatric renal transplantation observe a majority of deaths due to malignancies and infections but have no impact of cardiovascular disease (Allain-Launay et al. 2009). On the other hand careful follow-up studies have revealed that repolarization abnormalities shown on an electrocardiogram of pre-RT patients improved significantly after RT (QTc dispersion $50.8+/-37.3$ to $37.4+/-11.9 \mathrm{msec}, \mathrm{P}=0.009)$ and left ventricular hypertrophy with increased LV mass index of pre-RT patients regressed remarkably after RT (LV mass index 120.9+/40.5 to $69.2+/-14.5 \mathrm{~g} / \mathrm{m} 2, \mathrm{P}<0.001)$. Still $\mathrm{LV}$ mass was significantly higher in RT patients than the controls $(54.0+/-9.6 \mathrm{~g} / \mathrm{m} 2, \mathrm{P}<0.001)$. Compared to the controls, the RT patients showed diastolic dysfunction (lower E/A ratio and higher isovolumic relaxation time) and lower myocardial performance (higher LV Tei index and weaker strain pattern)( Kim et al. 2009). Other investigators too have observed persistent diastolic dysfunction following kidney transplantation in children (Ten Harkel et al . 2009).

\subsection{Convulsions}

Although this would be commonly alluded to drug toxicity (e.g. cyclosporine), in our set up, this could result from rapid loss of urea through the poly-uric transplanted kidney leading to a reverse osmosis and cerebral edema. Thus, the need for mechanical ventilation especially in children who had high blood urea levels pre-operatively (e.g. over $30 \mathrm{mmol} / \mathrm{l}$ ) is justifiable.

\subsection{Bleeding diathesis}

This often results from preoperative liver dysfunction (due to chronic congestion) and antiplatelet agents used for the prevention of acute vascular thrombosis. In chronically anemic patients, usually aspirin is avoided as the resulting bleed will not stop unless and until almost an exchange transfusion has occurred and the transfused platelets have taken effect. The need for leucocyte depleted blood to minimize the risk of sensitization, cryo precipitate and fresh frozen plasma in the management of this case scenario which is often an unbearable burden for our support services.

\subsection{Hyperglycemia}

Often a hyperglycemic state is noted, especially in children during the poly-uric phase. This is a direct result of the use of saline/dextrose solutions far exceeding the amounts the body 
can handle metabolically during the given time. The hyperglycemia noted in this post operative phase is not usually associated with a metabolic derangement as seen in, for example, in diabetic keto acidosis and it is often impossible to normalize glucose levels through insulin therapy during the ongoing replacement therapy with dextrose/saline. The use of, for example, $0.45 \%$ saline alone is also harmful due to its hypo tonicity. In our experience, this resultant hyperglycemia is relatively harmless and resolves spontaneously once the poly-uric phase is over.

\subsection{Drug monitoring}

It is not possible to monitor drug levels as much as one would like and more often than not an empirical dosage adjustment is carried out.

\subsection{Sepsis}

The mortality of pediatric renal transplant recipient is 4 to $4.5 \%$ in the long term; and in 40 $45 \%$ this mortality, is caused by infection.

\subsection{Our experience}

From among the 29 children receiving kidney transplantation in our centre over the last 6 years, all children received a standard general anesthetic (Biriulina e al 2008), balanced using a low-flow inhalational isoflurane with non- invasive BP monitoring combined with internal jugular vein catheterization for CVP monitoring. The major component of infusion therapy was freshly frozen plasma and leukocyte depleted blood to correct anemia and operative blood loss.

In our cohort, all were admitted to the ICU for postoperative mechanical ventilation following transplantation. The need to maintain adult blood pressures in children to drive the transplanted adult kidney with added problems of splinted diaphragm and a large proportion of the cardiac output diverting through the adult transplanted kidney imposed further difficulties for the already strained cardiovascular system in children. Thus, most children needed post operative intensive care necessitating inotropes and mechanical ventilation support. In our cohort, the mean $( \pm S D)$ duration of mechanical ventilation was $4.59 \pm 2.77$ days while the mean $( \pm \mathrm{SD})$ ICU stay was $6.44 \pm 3.35$ days. Post operative ICU complications occurred in $85.71 \%$.

Hypertension (53\%), heart failure (32\%) and convulsions (32\%) were the commonest problems. Hyperglycemia $(25 \%)$, bleeding diathesis $(25 \%)$, temporary transplant kidney failure needing dialysis, acute exacerbation of asthma, low calcium, lung collapse, hyponatremia, paralytic ileus, and cyclosporine toxicity were among the other complications. No ICU deaths of post renal transplant patients were reported.

We are only relieved that there were no patient or graft losses especially at this early phase of the program. This helped us build the much needed confidence of the public and that of colleagues. The experiences gained by the surgeon, nephrologists and anesthesiologist abroad in developed countries, contributed to this favorable outcome as they all functioned with a degree of anticipation for known complications and prevention. The nursing staff had no previous exposure but had learnt rapidly on the job using their intensive care skills to manage these cases.

It was not possible to make any statistically significant causal inferences with the present study as it comprised of a small number of cases and had relatively short duration of follow 
up. However, medical professionals develop the pattern of recognition necessary for infrequent clinical entities, through confrontation with real life demonstrations or lively papers best examples being case reports and case series. In this context, this paper would help those who are envisaging kidney transplant programmes in the developing world with limited resources.

\section{Limitations}

In a recent review, collating 16 reports of 300 pediatric transplants in the developing world found that recipients were older than 6 years and donors were living relatives in more than $94 \%$ of the series. Cyclosporine, azathioprin and steroids were the mainstay of immunosuppression and in many centers, the high costs of drugs resulted in noncompliance and discontinuation of immunosuppression. Therefore, acute rejection rates were high, more than $40 \%$ in half of the series. One-year and 5-year survival rates for grafts were 89 $98 \%$ and $67-84 \%$ and for patients $88-98 \%$ and $65-90 \%$, respectively. Major causes of graft loss were chronic rejection, acute rejection and infection and for the patients, it was infection. Growth analysis was not generally reported but when reported the deficit remains or gets worse. They concluded that high rejection and infection rates result in poor patient and graft survival (Rizvi et al 2009).

With increased awareness, improved resources, and more health professionals trained in the field, it is likely that the renal transplantation would be routine in Sri Lanka as in many other countries. Although it offers survival advantage to these children, it is a complex procedure and is not without complications. The financial implications of costly regular medications these children need is an intolerable blow to the affected families and hence we are working towards meeting these costs via charity.

Improving survival and quality of life for kidney transplant recipients in developing countries in the long-term is an awesome task. A recent review looking into factors affecting long-term outcome after renal transplantation in childhood, summarized in the table below would bring useful hints for the clinicians involved in caring for these children and adults in the developing world.

\section{Conclusion}

Kidney transplantation in the current context in a developing country may warrant a significant duration of postoperative ICU therapy in children. Since chronic dialysis also increases morbidity in these patients as it is associated with cardiovascular damage, impaired cognitive development and retardation of growth, pre-emptive kidney transplantation in children with ESRD, seems the treatment of choice in the developing world.

Minimizing the risk of chronic allograft nephropathy is invariably a major task during follow up. Appropriate titration of the immunosuppressive agents of the high-risk patients (such as in those with higher serum creatinine level ) will be very important. Compliance can be improved by regular supervision and education of the patients and the parents and being empathetic towards their problems and needs, (especially those of the adolescent child) and also by minimizing the unnecessary hospital admissions and clinic visits, making the drug prescriptions as less complicated as possible and timely attending to the unwanted side effects of the drugs. 


\begin{tabular}{|c|c|}
\hline $\begin{array}{l}\text { TRANSPLANT OUTCOME } \\
\text { DETERMINANTS }\end{array}$ & WHAT IS ALREADY KNOWN \\
\hline Factors influencing outcome & $\begin{array}{l}\text { - Available resources affect patient selection, follow- } \\
\text { up and drug regimens } \\
\text { Community attitudes influence treatment of high- } \\
\text { risk patients such as neonates and children with } \\
\text { handicaps } \\
\text { - Some diagnoses are more common in particular } \\
\text { ethnic backgrounds and patient and graft survival } \\
\text { are affected by racial group } \\
\text { The outcome is generally superior for LD } \\
\text { transplantation }\end{array}$ \\
\hline Patient survival & $\begin{array}{l}\text { - The mortality rate of children on the waiting list is } \\
55 \text { per } 1000 \text { at risk } \\
\text { The overall mortality rate, with a relative risk of } \\
\text { death after transplantation is } 12.7 \text {-times higher } \\
\text { than that of the age-related general population }\end{array}$ \\
\hline Overall patient survival & 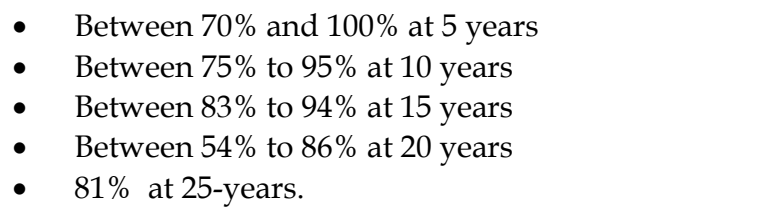 \\
\hline Effect of recipient age & $\begin{array}{l}\text { - Mortality twice as high in those }<5 \text { years of age } \\
\text { than in those } 6 \text { to } 10 \text { years old } \\
\text { 5-year survival rate of over } 97 \% \text { in under } 6 \text { year } \\
\text { olds } \\
\text { - } 91 \% 10 \text {-year survival rate in those weighing }<15 \mathrm{~kg} \\
\text { at transplantation } \\
87 \% 15 \text {-year survival rate in those }<11 \mathrm{~kg} \text { at } \\
\text { transplantation }\end{array}$ \\
\hline Effect of donor type & $\begin{array}{l}\text { - Small benefit of LD on mortality at all ages up to } \\
5 \text { years after transplantation } \\
\text { - The survival rate for recipients of LDs, } 96.1 \% \\
5 \text { years after transplantation } \\
\text { - } \quad \text { DD has a particular benefit for the very young } \\
\text { child: } 5 \text {-year patient survival rates for recipients } \\
\text { less than } 2 \text { years old was } 86 \% \text { following LD and } \\
70 \% \text { following DD }\end{array}$ \\
\hline $\begin{array}{l}\text { Causes of death after } \\
\text { transplantation }\end{array}$ & $\begin{array}{l}\text { - } \text { Cardiovascular disease (CVD) } 30-36 \% \\
\text { - } \quad \text { Infection } 24-56 \%\end{array}$ \\
\hline
\end{tabular}




\begin{tabular}{|c|c|}
\hline TRANSPLANT OUTCOME & WHAT IS ALREADY KNOWN \\
\hline & $\begin{array}{l}\text { - } \quad \text { Malignancy } 11-20 \% \\
\text { - Other important factors (a) non-concordance with } \\
\text { medications, or treatment withdrawal (b) obesity }\end{array}$ \\
\hline $\begin{array}{l}\text { Comparison of mortality after } \\
\text { transplantation with mortality } \\
\text { on dialysis }\end{array}$ & $\begin{array}{l}\text { - lifespan of a child on dialysis is } 40-60 \text { years less, } \\
\text { with a transplant, } 20-25 \text { years less, than that of age- } \\
\text { and race-matched general populations } \\
\text { Eighty percent of patients on HD, } 83 \% \text { of those on } \\
\text { PD and } 93 \% \text { of those with a transplant survive } \\
5 \text { years } \\
\text { - Mortality rates are seven-times higher in those } \\
\text { who have been on dialysis for longer than they } \\
\text { have had a transplant } \\
\text { Treatment with dialysis is associated with a risk } \\
\text { more than four-times as high as for renal } \\
\text { transplantation. } \\
\text { Most of the increased mortality in children on } \\
\text { dialysis is due to CVD } \\
\text { Adolescents who had undergone pre-emptive } \\
\text { transplantation have a better survival rate. }\end{array}$ \\
\hline Effect of race & $\begin{array}{l}\text { Poorer outcomes for Afro-Americans than for the } \\
\text { white population due to increased incidence of } \\
\text { cardiovascular deaths by approximately } 1.6 \text { times. } \\
\text { Among black patients, cardiac deaths occurred in } \\
11 \% \text { of transplant recipients and } 34 \% \text { of dialysis } \\
\text { patients, and, among white patients, } 9 \% \text { and } 25 \% \text {, } \\
\text { respectively }\end{array}$ \\
\hline Overall transplant survival & $\begin{array}{l}\text { - } \quad \text { Current projected half-life } 10 \text { years. } \\
\text { Given a median age at transplantation of } 13 \text { years, } \\
50 \% \text { of all current pediatric kidney recipients will } \\
\text { need a second graft before the age of } 25 \text { years } \\
\text { - Overall 5-year transplant survival varies between } \\
44 \% \text { to } 95 \% \\
\text { - } 5 \text { at } 5 \text { years, } 23 \%-95 \% \text { at } 10 \text { years, } 35 \% \text { at } 15 \text { years [ } 8 \text { ] } \\
\text { and } 21-36 \% \text { at } 20 \text { years. } \\
\text { - Graft survival of repeat transplants are slightly } \\
\text { lower than first grafts. } \\
\text { When DDs were used, graft survival rates at } 1,3 \\
\text { and } 5 \text { years were } 79 \%, 69 \% \text {, and } 62 \%, \text { compared } \\
\text { with } 74 \%, 60 \% \text {, and } 47 \%, \text { respectively, for the } \\
\text { repeat transplants }\end{array}$ \\
\hline
\end{tabular}




\begin{tabular}{|c|c|}
\hline TRANSPLANT OUTCOME & WHAT IS ALREADY KNOWN \\
\hline & $\begin{array}{l}\text { For LDs, graft survival rates for } 1,3 \text { and } 5 \text { years } \\
\text { were } 91 \%, 83 \% \text {, and } 76 \% \text { compared to } 86 \%, 78 \% \text {, } \\
\text { and } 72 \% \text {, respectively, for repeat transplants. }\end{array}$ \\
\hline Effect of recipient age & $\begin{array}{l}\text { - } \quad \text { Graft survival at } 1 \text { year and } 5 \text { years } \\
\text { - } 71 \% \text { and } 60 \% \text { in those under the age of } 2 \text { years at } \\
\text { - } 83 \% \text { and } 64 \% \text { in those aged } 3 \text { to } 12 \text { years } \\
\text { - } \quad 85 \% \text { and } 57 \% \text { in those aged } 13 \text { to } 21 \text { years } \\
\text { - } \quad \text { In adolescents, as a group, have the worst graft } \\
\text { survival rate of all ages }\end{array}$ \\
\hline Effect of donor age & $\begin{array}{l}\text { Kidneys from deceased donors aged } 11-17 \text { years } \\
\text { do best, with a } 73 \% 5 \text {-year survival } \\
\text { Transplant survival of } 55 \% \text { after } 5 \text { years, for donors } \\
<6 \text { years of age, and of } 60 \% \text { for donors over that } \\
\text { age } \\
\text { - } 5 \text {-year graft survival rate from donors }<1 \text { year of } \\
\text { age } 60 \% \text { and to } 70 \% \text { for donors aged } 1 \text { year to } \\
5 \text { years }\end{array}$ \\
\hline Effect of donor type & $\begin{array}{l}\text { - Living related donation (LD) benefit outcome, graft } \\
\text { survival } 75 \%-85 \% \text { at } 10 \text { years, compared to } 46 \% \\
\text { for DDs } \\
\text { - LRD is of particular benefit to the recipient under } \\
2 \text { years of age, 5-year graft survival } 86 \% \text { compared } \\
\text { to } 38 \% \text { following DD }\end{array}$ \\
\hline $\begin{array}{l}\text { Effect of pre-emptive } \\
\text { transplant }\end{array}$ & $\begin{array}{l}\text { Transplant survival better in patients receiving a } \\
\text { pre-emptive transplant compared with those } \\
\text { undergoing PD and HD. } \\
\text { Graft loss resulting from vascular thrombosis is } \\
\text { more common in children who undergo PD than in } \\
\text { those who on HD } \\
\text { - Graft survival between those not on dialysis and } \\
\text { those on dialysis of } 82 \% \text { and } 69 \% \text {, respectively, at } \\
6 \text { years } \\
\text { Waiting time on dialysis is an independent risk } \\
\text { factor for failure of LRD transplants in adolescents }\end{array}$ \\
\hline Recurrent diseases & $\begin{array}{l}\text { - Diseases that recur after transplantation with a } \\
\text { potential to affect outcome include FSGS, } \\
\text { membranoproliferative glomerulonephritis }\end{array}$ \\
\hline
\end{tabular}




\begin{tabular}{|c|c|}
\hline TRANSPLANT OUTCOME & WHAT IS ALREADY KNOWN \\
\hline & $\begin{array}{l}\text { (MPGN) and haemolytic uraemic syndrome (HUS) } \\
\text { Oxalate will continue to be deposited in the } \\
\text { transplant if liver transplantation is not undertaken } \\
\text { in patients with hyperoxaluria. } \\
\text { - Nephrotic syndrome can recur in patients with } \\
\text { congenital nephrotic syndrome, and anti- } \\
\text { glomerular basement membrane (anti-GBM) } \\
\text { nephritis in patients with Alport's syndrome, both } \\
\text { due to the development of antibody to the } \\
\text { 'missing' protein. } \\
\text { - FSGS recurs in approximately } 30 \% \text { of transplants }\end{array}$ \\
\hline $\begin{array}{l}\text { Human leukocyte antigen } \\
\text { matching }\end{array}$ & $\begin{array}{l}\text { Donor-specific HLA mismatching is a risk for poor } \\
\text { outcome } \\
\text { - Worst outcome has been observed for two HLA- } \\
\text { DR mismatched grafts } \\
\text { - } 000 \text { and favourably matched kidneys (100, 010, } 110 \\
\text { HLA-A, -B,-DR mismatches) survived longest } \\
\text { Sensitised patients [panel reactive antibodies } \\
\text { (PRA) }>40 \% \text { ]have a poorer outcome } \\
\text { Donor antigen-specific hyporeactivity correlates } \\
\text { with better graft function }\end{array}$ \\
\hline Immunosuppression & $\begin{array}{l}\text { - The use of MMF in association with ciclosporin is } \\
\text { associated with better outcome at } 5 \text { years than a } \\
\text { similar regimen using AZA, transplant survival's } \\
\text { being } 90.7 \% \text { for MMF and } 68.5 \% \text { for AZA patients. } \\
\text { - Cumulative rejection-free survival was also better } \\
\text { in the MMF group, at } 51.2 \% \text { versus } 37.0 \% \text { in AZA } \\
\text { patients. } \\
\text { Tacrolimus is significantly more effective than } \\
\text { ciclosporin in both preventing acute rejection and } \\
\text { maintaining graft function, with a } 4 \text {-year } \\
\text { transplant survival rate of } 86 \% \text { and } 69 \% \text {, } \\
\text { respectively }\end{array}$ \\
\hline $\begin{array}{l}\text { Concordance with therapeutic } \\
\text { regimens }\end{array}$ & $\begin{array}{l}\text { - Non-concordance with therapeutic regimens } \\
\text { affects all ages, but particularly adolescence. } \\
\text { Non-concordance is the main contributor for late } \\
\text { graft loss, accounting for } 71 \% \text { of cases, and was a } \\
\text { particular problem in Afro-American recipients }\end{array}$ \\
\hline Hypertension & - Very common after transplantation, and its \\
\hline
\end{tabular}




\begin{tabular}{|c|c|}
\hline $\begin{array}{l}\text { TRANSPLANT OUTCOME } \\
\text { DETERMINANTS }\end{array}$ & WHAT IS ALREADY KNOWN \\
\hline & $\begin{array}{l}\text { incidence varies with time, ranging from } 46 \%, 40 \% \text {, } \\
\text { and } 66 \% \text { of children at } 1,5 \text {, and } 10 \text { years, } \\
\text { respectively. } \\
\text { Hypertension is a significant and independent } \\
\text { predictor of poor long-term transplant function, } \\
\text { regardless of the number of rejection episodes or } \\
\text { transplant function at } 1 \text { year. }\end{array}$ \\
\hline Bladder dynamics & $\begin{array}{l}\text { - Transplantation into an abnormal urinary tract is } \\
\text { associated with a high incidence of urological and } \\
\text { infectious complications but no effect on patient } \\
\text { survival or transplant outcome. } \\
\text { - Careful surveillance of lower urinary tract function } \\
\text { by urodynamic evaluation is essential before } \\
\text { transplantation. } \\
\text { Reflux does not need to be corrected before } \\
\text { transplantation, unless it is causing symptoms or } \\
\text { infection. }\end{array}$ \\
\hline $\begin{array}{l}\text { Laparoscpic donor } \\
\text { nephrectomy }\end{array}$ & $\begin{array}{l}\text { Despite longer warm ischaemia and cold ischaemia } \\
\text { times in LDs, graft outcome does not seem to be } \\
\text { affected. }\end{array}$ \\
\hline $\begin{array}{l}\text { Final height and incidence of } \\
\text { obesity }\end{array}$ & $\begin{array}{l}\text { - Improvements in pre-transplantation management, } \\
\text { particularly nutrition, have led to a better height } \\
\text { attainment at transplantation } \\
\text { Decline in steroid dosing as immunosuppression } \\
\text { has a positive benefit on growth. Patients who } \\
\text { received recombinant human growth hormone } \\
\text { (rHGH) suggest that final height is better than for } \\
\text { those not receiving it. } \\
\text { Obesity, defined by a body mass index (BMI) }>95 \text { th } \\
\text { centile, is increasing in the transplant population } \\
\text { (12.4\% after } 1995 \text { and } 8 \% \text { before } 1995) \text { and seems to } \\
\text { be more common in girls. }\end{array}$ \\
\hline Psychosocial outcome & $\begin{array}{l}\text { Psychosocial outcome seems to be better after } \\
\text { transplantation than for patients on dialysis. } \\
\text { Employment: Several studies have revealed } \\
\text { satisfactory employment levels., The range of } \\
\text { occupations is broad, with a normal average } \\
\text { working time each week. } \\
\text { Relationships: Successful relationships are reported } \\
\text { - } 0 \% \text { married }\end{array}$ \\
\hline
\end{tabular}




\begin{tabular}{|c|c|}
\hline TRANSPLANT OUTCOME & WHAT IS ALREADY KNOWN \\
\hline & $\begin{array}{l}\text { Physical morbidity: Co-morbidity was found in } \\
40 \% \text { of all patients: motor, hearing, or visual } \\
\text { disabilities were found in } 19 \% \text {. Bone disease, } \\
\text { headaches, itching, and tremors were the most } \\
\text { reported disabling problems. Other complications } \\
\text { included osteoporosis in } 53 \% \text { of patients, avascular } \\
\text { bone necrosis in } 13 \% \text {, post-transplantation diabetes } \\
\text { mellitus in } 10 \% \text {, and hypertension in } 60 \% \text {. } \\
\text { Education: Distribution of educational level was } \\
\text { lower than national averages: } 27.4 \% \text { were at the } \\
\text { lowest level versus } 3 \% \text { of the general population, } \\
41.4 \% \text { were at the middle level, } 31.2 \% \text { had reached } \\
\text { the baccalaureate level, and } 11 \% \text { had followed a } \\
\text { university course. }\end{array}$ \\
\hline Independence & $\begin{array}{l}\text { - } \quad 46 \% \text { lived in their parents' home } \\
\text { - } \quad 54 \% \text { lived independently }\end{array}$ \\
\hline
\end{tabular}

Table 1. A summary of long-term outcome after renal transplantation in childhood (Rees 2009).

In spite of increase graft survival, mortality rates of renal transplant patients remain higher than the normal population. Cardio-vascular diseases, de-novo malignancy and infections are the commonest causes of death in the long run. Careful management of hypertension, left ventricular hypertrophy, dyslipidaemias and calcium and phosphate homeostasis, from the pre-transplant period, would help to reduce the cardio-vascular related deaths. Incidence of infections and malignancy can be reduced by the appropriate selection of the immune-suppressive drugs with timely tailoring off the dosages in patients, who are at lower risk for rejection.

Another important challenge ahead is to optimize the care given to the patient with chronic kidney disease or CRF. One of the main obstacles that prevent this is the late presentation of these patients. Increased awareness of the health personnel and the general public regarding identification of the patients with renal problems and appropriate management of them will invariably reduce the incidence of ESRF, and better care provided to the CRF patients will delay the progression to end stage and will also reduce the pre-operative co-morbidities.

In addition, the provision of regular medication, improving laboratory facilities, establishment of pediatric dialysis programmes and increasing the number of resource persons (pediatric transplant surgeons, pediatric nephrologists, pediatric anesthetists and trained paramedical personnel) are important goals to be achieved in the future, to assure successful ongoing transplant programs in the developing world.

\section{Acknowledgements}

The author especially acknowledge the contributions made by the nephrologists Abeysekara C K, Abegunawardena A, Abeysekara T, Wazil M, and the surgeons Fernando O, Buthpitiya 
AG, Lamawansa MD for the sustenance of above pediatric kidney transplant program assisted by B Hevavithana (Radiologist), Dr N Ratnatunga (Pathologist) and all other hospital staff and Mr Mahes Salgado for assistance with the manuscript.

\section{References}

Aalten J. Bemelman FJ. van den Berg-Loonen EM. Claas FH. Christiaans MH. de Fijter JW. Hepkema BG. Hene RJ. van der Heide JJ. van Hooff JP. Lardy NM. Lems SP. Otten HG. Weimar W. Allebes WA. Hoitsma AJ. (2009 Aug) Pre-kidney-transplant blood transfusions do not improve transplantation outcome: a Dutch national study. Nephrology Dialysis Transplantation. 24(8):2559-66

Allain-Launay E. Roussey-Kesler G. Ranchin B. Guest G. Maisin A. Novo R. Andre JL. Cloarec S. Guyot C. (2009 Sep) Mortality in pediatric renal transplantation: a study of the French pediatric kidney database. Pediatric Transplantation. 13(6):725-30

Badmus TA. Arogundade FA. Sanusi AA. Akinsola WA. Adesunkanmi AR. Agbakwuru AO. Salako AB. Faponle AF. Oyebamiji EO. Adetiloye VA. Famurewa OC. Oladimeji BY. Fatoye FO (2005) Kidney transplantation in a developing economy: challenges and initial report of three cases at Ile Ife. . Central African Journal of Medicine. 51(9-10):102-6.

Bamgboye EL. (2009) Barriers to a functional renal transplant program in developing countries. Ethnicity \& Disease. 19(1 Suppl 1):S1-56-9.

Biriulina NIu. Ushakova IA. Vabishchevich AV. ( 2008 Sep-Oct.) [Anesthetic maintenance of renal transplantation in children]. [Russian] Anesteziologiia i Reanimatologiia. (5):58-61

Caliskan Y. Yazici H. Gorgulu N. Yelken B. Emre T. Turkmen A. Yildiz A. Aysuna N. Bozfakioglu S. Sever MS.( 2009 Feb ) Effect of pre-transplant dialysis modality on kidney transplantation outcome. Peritoneal Dialysis International. 29 Suppl 2:S11722.

Haberal M. Karakayali H. Sevmis S. Akbulut S. Colak T. Baskin E. Moray G. Torgay A. Arslan G. (2009 Sept) Preemptive living donor renal transplantation: a singlecenter experience. Transplantation Proceedings. 41(7):2764-7.

Irtan S. Maisin A. Baudouin V. Nivoche Y. Azoulay R. Jacqz-Aigrain E. El Ghoneimi A. Aigrain Y (2010 Jun) Renal transplantation in children: critical analysis of age related surgical complications. Pediatric Transplantation. 14(4):512-9.

Jung GO. Moon JI. Kim JM. Choi GS. Kwon CH. Cho JW. Kim SJ.(2007 Apr) Can preemptive kidney transplantation guarantee longer graft survival in living-donor kidney transplantation? Single-center study. Transplantation Proceedings. 42(3):766-74.

Kandus A. Arnol M. Bren AF.(2009 Aug) Survey of renal transplantation in Slovenia. Therapeutic Apheresis \& Dialysis: Official Peer-Reviewed Journal of the International Society for Apheresis, the Japanese Society for Apheresis, the Japanese Society for Dialysis Therapy. 13(4):264-7

Kim GB. Kwon BS. Kang HG. Ha JW. Ha IS. Noh CI. Choi JY. Kim SJ. Yun YS. Bae EJ. (2009 Jun 15). Cardiac dysfunction after renal transplantation; incomplete resolution in pediatric population. Transplantation. 87(11):1737-43 
Koshy SM. Guttmann A. Hebert D. Parkes RK. Logan AG (2009 Dec) Incidence and risk factors for cardiovascular events and death in pediatric renal transplant patients: a single center long-term outcome study. . Pediatric Transplantation. 13(8):1027-33

Muthusethupathi MA. Shivakumar S.(1993 Mar) Renal transplantation in India-problems and prospects. Journal of the Association of Physicians of India. 41(3):129.

Ng KH. Shrestha P. Aragon E. Lau YW. Yeo WS. Chan YH. Krishnan P. Yap HK.(2009 Apr) Nineteen-year experience of paediatric renal transplantation in Singapore. Annals of the Academy of Medicine, Singapore. 38(4):300-9.

Persy VP. Remuzzi G. Perico N. Benghanem Gharbi M. Adu D. Jha V. Rizvi A. Ben Ammar M. Fongoro S. De Broe ME. (2010) Prevention and transplantation in chronic kidney disease: what is achievable in emerging countries? Meeting report: Bamako meeting December 4-6, 2008. Nephron. 115(2):c122-32.

Porrett PM. Kamoun M. Parsons R. Bloom R. Goral S. Reese P. Grossman R. Baluarte J. Bleicher M. Doyle A. Markmann JF. Levine M. Barker C. Olthoff K. Naji A. Shaked A. Abt P.(2009) Kidney transplantation at the University of Pennsylvania: 19982008. . Clinical Transplants. :143-52.

Rees L. Long-term outcome after renal transplantation in childhood. [Review] 2009 Mar. Pediatric Nephrology. 24(3):475-84

Rizvi A. Naqvi A. Hussain Z. Hussain M. Hashmi A. Akhtar F. Zafar MN. Ahmed E. Sultan S. Aziz S. Shehzad A. Khalid R. . (2001 Feb-Mar) Why is it more difficult to transplant children? A perspective in developing countries. Transplantation Proceedings 33(1-2):1742-3,

Rizvi SA. Naqvi SA (1997 Feb-Mar) Need for increasing transplant activity: a sustainable model for developing countries. Transplantation Proceedings. 29(1-2):1560-2

Rizvi SA. Naqvi SA. Hussain Z. Hashmi A. Akhtar F. Hussain M. Ahmed E. Zafar MN. Hafiz S. Muzaffar R. Jawad F.(2003 Feb) Renal transplantation in developing countries. [Review] Kidney International - Supplement. (83):S96-100.

Rizvi SA. Zafar MN. Lanewala AA. Naqvi SA. (2009 Oct) Challenges in pediatric renal transplantation in developing countries. [Review] Current Opinion in Organ Transplantation. 14(5):533-9

Sakhaee K. (2010 Feb) . Post-renal transplantation hypophosphatemia. [Review] Pediatric Nephrology. 25(2):213-20

Ten Harkel AD. Cransberg K. Van Osch-Gevers M. Nauta J.(2009 Jun). Diastolic dysfunction in paediatric patients on peritoneal dialysis and after renal transplantation. Nephrology Dialysis Transplantation. 24(6):1987-91

Uchida K. (2010 Sep) [Pediatric renal transplant in Japan]. [Review] [Japanese] Nippon Geka Gakkai Zasshi. Journal of Japan Surgical Society. 111(5):299-304.

Usta A. Shawish T. Mishra A. Ehtuish EF. Ajaj H. Milud N. Shebani A. Abdulmola T. Tejori U. (2008 Dec) Living related kidney transplantation in Libya: a single center experience. Transplantation Proceedings. 40(10):3428-33.

van Heurn E. de Vries EE (2009 May) Kidney transplantation and donation in children. [Review]. Pediatric Surgery International. 25(5):385-93. 
Wisanuyotin S. Jiravuttipong A.(2009 Dec) Pediatric renal transplantation: a single-center experience in northeast Thailand. Journal of the Medical Association of Thailand. 92(12):1635-9. 


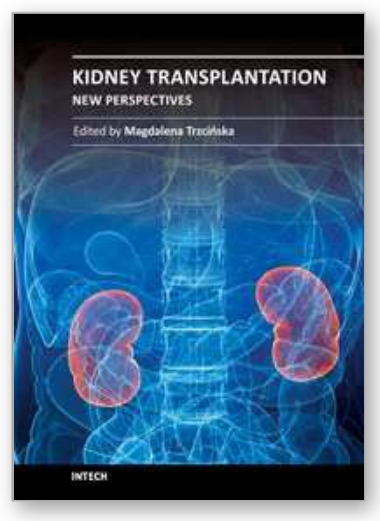

\author{
Kidney Transplantation - New Perspectives \\ Edited by Dr Magdalena Trzcinska
}

ISBN 978-953-307-684-3

Hard cover, 334 pages

Publisher InTech

Published online 23, August, 2011

Published in print edition August, 2011

Although many years have passed since the first successful kidney transplantation, the method, although no longer considered a medical experiment, is still perceived as controversial and, as such, it triggers many emotions and thatâ $\epsilon^{\mathrm{TM}} \mathrm{S}$ why conscious educational efforts are still needed for kidney transplantation, for many people being the only chance for an active lifestyle and improved quality of life, to win common social acceptance and stop triggering negative connotations. Apart from transplantation controversies piling up over years transplantologists also have to face many other medical difficulties. The chapters selected for this book are of high level of content, and the fact that their authors come from many different countries, and sometimes even cultures, has facilitated a comprehensive and interesting approach to the problem of kidney transplantation. The authors cover a wide spectrum of transplant-related topics.

\title{
How to reference
}

In order to correctly reference this scholarly work, feel free to copy and paste the following:

Chulananda DA Goonasekera (2011). Bridging the 'Gap' in Developing Countries: At what Expense?, Kidney Transplantation - New Perspectives, Dr Magdalena Trzcinska (Ed.), ISBN: 978-953-307-684-3, InTech, Available from: http://www.intechopen.com/books/kidney-transplantation-new-perspectives/bridging-the-gapin-developing-countries-at-what-expense-

\section{INTECH}

open science | open minds

\author{
InTech Europe \\ University Campus STeP Ri \\ Slavka Krautzeka 83/A \\ 51000 Rijeka, Croatia \\ Phone: +385 (51) 770447 \\ Fax: +385 (51) 686166 \\ www.intechopen.com
}

\author{
InTech China \\ Unit 405, Office Block, Hotel Equatorial Shanghai \\ No.65, Yan An Road (West), Shanghai, 200040, China \\ 中国上海市延安西路65号上海国际贵都大饭店办公楼405单元 \\ Phone: +86-21-62489820 \\ Fax: +86-21-62489821
}


(C) 2011 The Author(s). Licensee IntechOpen. This chapter is distributed under the terms of the Creative Commons Attribution-NonCommercialShareAlike-3.0 License, which permits use, distribution and reproduction for non-commercial purposes, provided the original is properly cited and derivative works building on this content are distributed under the same license. 